Egyptian Journal of Aquatic Biology \& Fisheries

Zoology Department, Faculty of Science,

Ain Shams University, Cairo, Egypt.

ISSN $1110-6131$

Vol. 22(5): $523-536(2018)$

www.ejabf.journals.ekb.eg

\title{
The impact of maritime activities on the leachable heavy metals in the seafloor sediments of Port Tawfiq and Tersana harbours, Gulf of Suez, Egypt
}

\author{
Ahmad R. Elgendy ${ }^{1}$, Mohamed A. Hassaan ${ }^{1^{*}}$ Farouk A. Soliman ${ }^{2}$ \\ and Mahmoud A. Dar ${ }^{1}$ \\ 1- Marine Environment Division, National Institute of Oceanography and Fisheries, \\ Egypt \\ 2- Geology Department, Faculty of Science, Suez Canal University, Egypt. \\ *Corresponding author: Mhss95@ mail.com and ma.hassaan@niof.sci.eg
}

\section{ARTICLE INFO \\ Article History: \\ Received: Dec. 4, 2018 \\ Accepted:Dec.30, 2018 \\ Online: Jan. 2019}

Keywords:

Maritime activities

Heavy Metals

Suez Gulf

Port Tawfiq

Fine Sediments Group

Bulk Sediments

\section{ABSTRACT}

The bulk sediment samples and the finest sediment group (FSG) including $(\varnothing 3, \varnothing 4$ and $<\varnothing 4)$ were used to estimate the leachable forms of Fe, $\mathrm{Mn}, \mathrm{Zn}, \mathrm{Cu}, \mathrm{Ni}, \mathrm{Pb}, \mathrm{Co}$ and $\mathrm{Cd}$ at Port Tawfiq and Tersana harbours in the Suez Bay at the northern tip of Suez Gulf using flame atomic absorption spectrophotometer (AAS). FSG was representing the essential constituents of the seafloor sediments with averages of $71.68 \%$ from the total sediments at Port Tawfiq Harbour and $69.47 \%$ at Tersana Harbour indicating the deposition under calm conditions. Leachable Fe was the metal carrier for the different heavy metals, the average leachable forms of $\mathrm{Fe}, \mathrm{Mn}$ and $\mathrm{Pb}$ in FSG (53382.81, 60048.81 $\mu \mathrm{g} / \mathrm{g}),(625.68,662.54 \mu \mathrm{g} / \mathrm{g})$ and $(55.191,67.23 \mu \mathrm{g} / \mathrm{g})$ about two folds in the bulk sediment $(26397.11,27761.07 \mu \mathrm{g} / \mathrm{g}),(219.05$, $224.22 \mu \mathrm{g} / \mathrm{g})$ and $(26.62,30.47 \mu \mathrm{g} / \mathrm{g})$ at both Port Tawfiq and Tersana harours respectively. Zn in FSG $(594.40 \mu \mathrm{g} / \mathrm{g})$ about two folds in the bulk sediments $(236.34 \mu \mathrm{g} / \mathrm{g})$ at Port Tawfiq Harbour, meanwhile at Tersana Harbour $\mathrm{Zn}$ in FSG $(968.58 \mu \mathrm{g} / \mathrm{g})$ about four folds in the bulk sediments $(265.25 \mu \mathrm{g} / \mathrm{g})$ respectively. The average leachable of $\mathrm{Cu}$ at Port Tawfiq Harbour in FSG $(303.50 \mu \mathrm{g} / \mathrm{g})$ recorded about three folds in the bulk sediments $(98.01 \mu \mathrm{g} / \mathrm{g})$, while at Tersana Harbour $(1020.33 \mu \mathrm{g} / \mathrm{g})$ recorded about five folds in the bulk sediments $(98.01 \mu \mathrm{g} / \mathrm{g})$. At Port Tawfiq Harbour in the FSG, the average leachable Ni $(211.47 \mu \mathrm{g} / \mathrm{g})$ exceeds more than four folds in the bulk sediments (50.13), meanwhile at Tersana Harbour in FSG $(507.75 \mu \mathrm{g} / \mathrm{g})$ about eight folds in the bulk sediments $(62.08 \mu \mathrm{g} / \mathrm{g})$. In the same Manner, the averages of leachable Co in FSG were about one time and half in the bulk sediments at the two studied harbours.

\section{INTRODUCTION}

The overseas maritime trades of Egypt were concentrated mainly in the Gulf of Suez and Suez Canal. The significance of the Suez Canal Suez is not limited to Egypt; it extends to all other world countries because of the size of this channel for international trade. The volume of global trade that passes through this channel ranges between $8 \%$ and $12 \%$ of total world trade. Suez Canal for Egypt is a very excellent source of income. The revenues of this channel in 2014 were about 39 billion pounds. The volume of trade passing by the Suez Canal in 2016 is about 998.654 about 1000 net ton, (SCA, 2016; Elgendy et al. 2018). 
Fine sediment forms are the most effective on changes of the geological and geochemical characteristics of the sediments at these harbours as the result of Maritime activities. The Gulf of Suez is extended for about $255 \mathrm{~km}$ with a width between 17 and $45 \mathrm{~km}$ and maximum depth of $83 \mathrm{~m}$ (UNEP, 1997). Throughout its geological history, the Gulf of Suez has always been a site of immense sediment accumulations (Behairy et al., 1992) from the flash flood wadis throughout its eastern and western banks. Accordingly, the Gulf of Suez has simple and gentle bottom morphological features with likewise gentle submarine coastal slopes.

This excessive sedimentation has also restrained the development of coral reefs (Behairy et al., 1992; Fouda and Gerges, 1994). The form or "chemical speciation" of metals varies widely depending on the environmental conditions. Such differences in chemical speciation affect the bioavailability, environmental risk, and environmental fate of these heavy metals (Martínez-Sánchez et al., 2008; Hassaan et al., 2016 ; Hassaan et al., 2017; El-Rayis et al., 2014) depending upon the chemistry and sediment structure, metal mobility, solubility, toxicity and reachability (Garcia et al., 2007). The mobile forms of heavy metals are the exchangeable phases of these metals that represent the bio-available toxic hazards in the marine environment. The exchange from one phase to another in the marine environment is controlled by the continuity of reworking operations in the surface of marine sediments (Dar et al., 2016a). The fine fraction sediments are also has a high capacity to retain heavy metals compared to other fractions (Abrahim et al. 2007; Nobi et al. 2010). The retention of heavy metals in the marine sediments is probably controlled by the rates of finest fractions accumulation, the organic matter decomposition and $\mathrm{Fe}$ and $\mathrm{Mn}$ concentrations. In anoxic conditions, hydroxides and sulphate reduction produce metal sulfides which are the more stable phase. Conversely, metal recycling in these ecosystems is attributed to oxic conditions prevailing (Dar and El Saharty, 2006; Hassaan and El-Rayis 2018; Hassaan and Ali, 2017; Hassaan et al., 2017b).

The present study aims to evaluate the effects of maritime activities on the geological and geochemical characteristics of the bottom sediments inside the navigation harbours of the two studied harbours (Port Tawfiq and Terrassa harbours) through estimation the concentrations of some leachable heavy metals such as $\mathrm{Fe}$, $\mathrm{Mn}, \mathrm{Zn}, \mathrm{Cu}, \mathrm{Ni}, \mathrm{Pb}, \mathrm{Co}$ and $\mathrm{Cd}$.

\section{MATERIALS AND METHODS}

The main activity of Port Tawfiq and Tersana harbors $\left(29^{\circ} 56^{\prime} \mathrm{N}-32^{\circ} 34^{\prime} \mathrm{E}\right)$ is the cargo and passenger hunch. These harbours are located on the northern end of the Gulf of Suez at the lateral entrance of the Suez Canal. The area includes the northern coast to the entrance of the Suez Canal and the floor area is $2.3 \mathrm{~km}^{2}$. The maximum design capacity is 3.5 million tons per year (General cargo 6.5 million tons per year and 2.5 million passengers annually) (GARSP, 2017).

Twenty seafloor sediments samples were collected from Port Tawfiq and nine samples from Tersana Harbours (Fig. 1). After washing and dried the samples sieved using mechanical shaker every one $\varnothing$ interval to estimate the main sediment constituents according to (Folk, 1974).

Carbonate content (expressed as $\mathrm{CO}_{3} \%$ ) was determined in the bulk samples. Accurately weighed powdered samples $(1 \mathrm{gm})$ were shaken with appropriate volume of diluted glacial acetic acid $(25 \mathrm{ml})$ over night. 


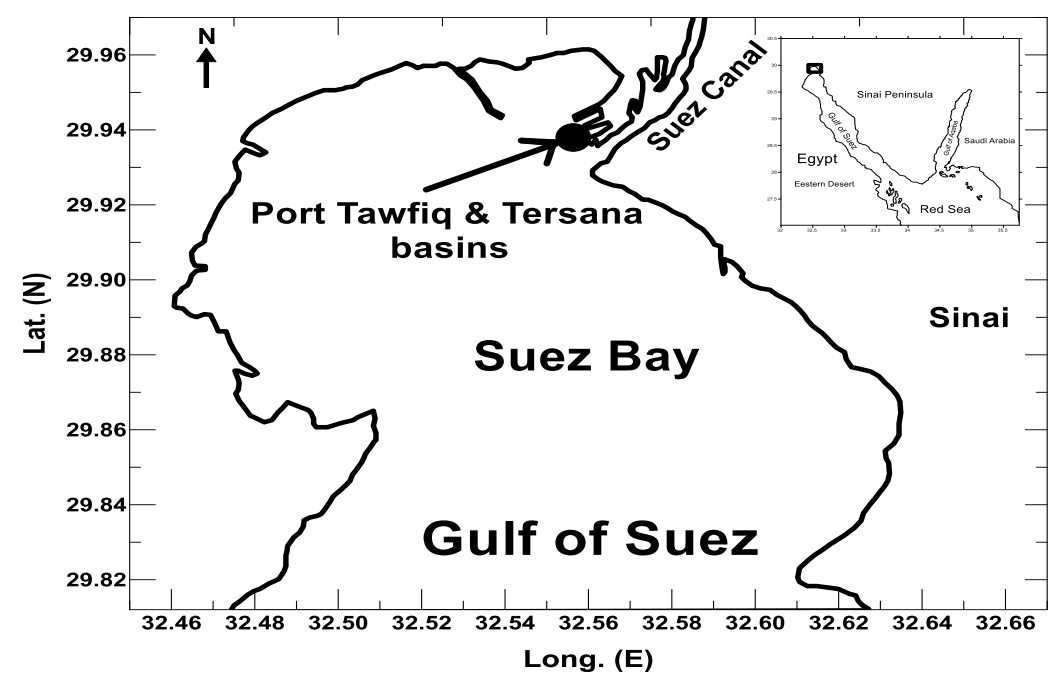

Fig. 1: A map of the two studied areas (Port Tawfiq and Tersana harbours).

The residues were then dried and the weight loss was considered as representing the carbonate content, given as percentage of the total weight (Basaham and El-Sayed, 1998; Dar et al., 2016a). Carbonate percentage was calculated according to the following equation:

$\mathrm{CO}_{3} \%=\frac{\text { wt. of sample }- \text { wt. of residue }}{\text { wt.of sample }} \times 100$

One gram of each bulk sample was burned to ash at $550^{\circ} \mathrm{C}$ for about two hours. The organic matter content of the sediments was calculated from sequential weight loss (Dean, 1974; Flannery et al., 1982 \& Brenner and Binford, 1988).Total organic matter content was estimated according to the following equation:

TOM $\%==\frac{\text { wt. of sample }- \text { wt. of ash }}{\text { wt. of sample }} \times 10$

The leachable forms of; $\mathrm{Fe}, \mathrm{Mn}, \mathrm{Zn}, \mathrm{Cu}, \mathrm{Ni}, \mathrm{Pb}, \mathrm{Co}$ and $\mathrm{Cd}$ were also measured using the flame AAS technique in both bulk and FSG samples according to (Chester et al., 1994 and Hassaan, 2010). Heavy metal concentrations (in $\mu \mathrm{g} / \mathrm{g}$ ) were measured by complete digestion. Before digestion to analyze heavy metals, each sample was dried at $65{ }^{\circ} \mathrm{C}$ for $48 \mathrm{~h}$ then, $0.5 \mathrm{gm}$ of well grinded and dried samples $(0.125,0.063$ and pan fractions) and $(\varnothing 3, \varnothing 4 \&<\varnothing 4)$ were immersed in $10 \mathrm{ml}$ of $\mathrm{HNO}_{3} / \mathrm{HCLO}_{4}$ acid mixture ( $70 \%$ purity), to investigate the effect of the maritime activities in the selected harbours, this approach were done according to (Chester et al., 1994), All treatments were performed in triplicate for each sample. The distribution patterns of heavy metal contents inside the Harbour were drawn by golden software surfer Ver. 13. The estimated correlation coefficient relationships were computed and figured using Excel 10, Graph Prism 6.0 and Wingraph 10.0.

\section{RESULTS}

\section{Port Tawfiq Harbour:}

Carbonate percentage $\left(\mathrm{CO}_{3} \%\right)$ and total organic matter percentage (TOM\%) were investigated in the bulk samples only. Carbonate percentage at Port Tawfiq Harbor was changed between $14.95 \%$ and $69.79 \%$ with an average of $44.24 \%$, while the percentage of the TOM percentage was ranged between $10.74 \%$ and $20.75 \%$ with average of $15.86 \%$ (Table 1 ). 
Table 1: The average values of heavy metals $(\mu \mathrm{g} / \mathrm{g})$ in the bulk sediments and FSG and Carbonate content $(\mathrm{CO3} \%)$ and total organic matter (TOM\%) in the bulk sediments only at Port Tawfiq and Tersana harbours.

\begin{tabular}{|c|c|c|c|c|c|c|c|c|c|c|}
\hline Bulk & $\mathbf{F e}$ & Mn & $\mathbf{Z n}$ & $\mathrm{Cu}$ & $\mathbf{N i}$ & $\mathbf{P b}$ & Co & Cd & $\mathrm{CO3 \%}$ & TOM \% \\
\hline Port Tawfiq & 26397.11 & 219.05 & 236.34 & 98.01 & 50.13 & 26.62 & 8.58 & 0.05 & 44.24 & 15.86 \\
\hline Tersana & 27761.07 & 224.22 & 265.25 & 209.30 & 62.08 & 30.47 & 6.50 & 0.16 & 44.93 & 21.70 \\
\hline FSG & $\mathbf{F e}$ & Mn & $\overline{Z n}$ & $\mathrm{Cu}$ & $\mathbf{N i}$ & $\overline{\mathbf{P b}}$ & Co & Cd & $\mathrm{CO3 \%}$ & TOM \% \\
\hline Port Tawfiq & 53382.81 & 625.68 & 594.40 & 303.50 & 211.47 & 55.19 & 11.49 & 0.87 & $\mathrm{ND}^{*}$ & ND \\
\hline Tersana & 60048.82 & 662.55 & 968.58 & 1020.33 & 507.75 & 67.24 & 9.47 & 1.97 & ND & ND \\
\hline
\end{tabular}

ND = Not Determined

The leachable Fe in the bulk sediments was ranged between $10105.80 \mu \mathrm{g} / \mathrm{g}$ and $43351.26 \mu \mathrm{g} / \mathrm{g}$ with an average of $26397.11 \mu \mathrm{g} / \mathrm{g}$, meanwhile, FSG showed the variation from $38099.54 \mu \mathrm{g} / \mathrm{g}$ to $73240.93 \mu \mathrm{g} / \mathrm{g}$ with an average of $53382.81 \mu \mathrm{g} / \mathrm{g}$. In the bulk sediments leachable Mn was increased from $74.98 \mu \mathrm{g} / \mathrm{g}$ to $434.58 \mu \mathrm{g} / \mathrm{g}$ with average of $219.05 \mu \mathrm{g} / \mathrm{g}$, while in the FSG, it was increased from $446.93 \mu \mathrm{g} / \mathrm{g}$ to $941.26 \mu \mathrm{g} / \mathrm{g}$ with an average of $625.68 \mu \mathrm{g} / \mathrm{g}$. Leachable $\mathrm{Zn}$ in the bulk sediments was fluctuated between $(64.95 \mu \mathrm{g} / \mathrm{g})$ and $(642.67 \mu \mathrm{g} / \mathrm{g})$ with an average of $236.34 \mu \mathrm{g} / \mathrm{g}$ and in the FSG, Zn was fluctuated between $173.61 \mu \mathrm{g} / \mathrm{g}$ and $1127.20 \mu \mathrm{g} / \mathrm{g}$ with an average of $594.40 \mu \mathrm{g} / \mathrm{g}$. Leachable $\mathrm{Cu}$ in the bulk sediments showed variation from $14.49 \mu \mathrm{g} / \mathrm{g}$ to $253.75 \mu \mathrm{g} / \mathrm{g}$ with an average of $98.01 \mu \mathrm{g} / \mathrm{g}$ and in the FSG, Cu was varied between $51.41 \mu \mathrm{g} / \mathrm{g}$ and $552.54 \mu \mathrm{g} / \mathrm{g}$ averaging of $303.50 \mu \mathrm{g} / \mathrm{g}$. Leachable $\mathrm{Ni}$ in the bulk sediments was changed between $17.73 \mu \mathrm{g} / \mathrm{g}$ and $41.93 \mu \mathrm{g} / \mathrm{g}$ with an average of $26.62 \mu \mathrm{g} / \mathrm{g}$; in the FSG, Ni was fluctuated between $24.30 \mu \mathrm{g} / \mathrm{g}$ and $84.69 \mu \mathrm{g} / \mathrm{g}$ with an average of $55.19 \mu \mathrm{g} / \mathrm{g}$. Leachable $\mathrm{Pb}$ in the bulk sediments was declined from $118.06 \mu \mathrm{g} / \mathrm{g}$ to $1.51 \mu \mathrm{g} / \mathrm{g}$ with an average of $51.13 \mu \mathrm{g} / \mathrm{g}$, meanwhile in the FSG, Pb was declined from $509.14 \mu \mathrm{g} / \mathrm{g}$ to $61.45 \mu \mathrm{g} / \mathrm{g}$ averaging of $211.47 \mu \mathrm{g} / \mathrm{g}$. Leachable Co in the bulk sediments was ranged between below the detection limit to $15.93 \mu \mathrm{g} / \mathrm{g}$ averaging of $8.58 \mu \mathrm{g} / \mathrm{g}$, while in the FSG, Co was fluctuated between $4.57 \mu \mathrm{g} / \mathrm{g}$ and $22.73 \mu \mathrm{g} / \mathrm{g}$ with average of $11.49 \mu \mathrm{g} / \mathrm{g}$. Leachable $\mathrm{Cd}$ in the bulk sediments was insignificant, meanwhile in the FSG Cd was increased from below the detection limit to $4.12 \mu \mathrm{g} / \mathrm{g}$ averaging of $0.87 \mu \mathrm{g} / \mathrm{g}$ (Table 1 ).

\section{Tersana Harbour:}

The percentage of $\mathrm{CO}_{3} \%$ in the bulk sediments at Tersana Harbor was fluctuated between $37.10 \%$ and $61.77 \%$ with an average $44.93 \%$, while the percentage of TOM showed the variation from $14.57 \%$ to $25.36 \%$ and the average of $21.70 \%$ (Table 1 ).

The leachable $\mathrm{Fe}$ in the bulk sediments at Tersana Harbor was varied from $14345.04 \mu \mathrm{g} / \mathrm{g}$ to $41713.42 \mu \mathrm{g} / \mathrm{g}$ with an average of $31173.07 \mu \mathrm{g} / \mathrm{g}$, meanwhile, in the FSG, Fe was varied from $42157.88 \mu \mathrm{g} / \mathrm{g}$ to $73718.20 \mu \mathrm{g} / \mathrm{g}$ with an average of $60048.82 \mu \mathrm{g} / \mathrm{g}$. The leachable $\mathrm{Mn}$ in the bulk sediments was declined from $291.05 \mu \mathrm{g} / \mathrm{g}$ to $138.44 \mu \mathrm{g} / \mathrm{g}$ with an average of $229.50 \mu \mathrm{g} / \mathrm{g}$, meanwhile, in the FSG, Mn was declined from $500.83 \mu \mathrm{g} / \mathrm{g}$ to $757.21 \mu \mathrm{g} / \mathrm{g}$ with an average of $(662.55 \mu \mathrm{g} / \mathrm{g})$. $\mathrm{Zn}$ leachable in the bulk sediments was changed between $127.53 \mu \mathrm{g} / \mathrm{g}$ and $450.64 \mu \mathrm{g} / \mathrm{g}$ with an average of $313.02 \mu \mathrm{g} / \mathrm{g}$, while in the FSG; Zn was fluctuated between $480.76 \mu \mathrm{g} / \mathrm{g}$ and $1662.90 \mu \mathrm{g} / \mathrm{g}$ with an average of $968.58 \mu \mathrm{g} / \mathrm{g}$. In the bulk sediments, the leachable $\mathrm{Cu}$ was changed between $23.55 \mu \mathrm{g} / \mathrm{g}$ and $1053.65 \mu \mathrm{g} / \mathrm{g}$ with an average of $485.70 \mu \mathrm{g} / \mathrm{g}$ and in the FSG; $\mathrm{Cu}$ was increased from $46.04 \mu \mathrm{g} / \mathrm{g}$ to $2209.40 \mu \mathrm{g} / \mathrm{g}$ with an average of $1020.33 \mu \mathrm{g} / \mathrm{g}$. In the same affair, the leachable Ni was changed between $20.93 \mu \mathrm{g} / \mathrm{g}$ and $99.41 \mu \mathrm{g} / \mathrm{g}$ with an average of $39.59 \mu \mathrm{g} / \mathrm{gin}$ the bulk sediments, meanwhile in the FSG, Ni was fluctuated between $20.37 \mu \mathrm{g} / \mathrm{g}$ and $106.66 \mu \mathrm{g} / \mathrm{g}$ with an average of $67.24 \mu \mathrm{g} / \mathrm{g}$. The leachable $\mathrm{Pb}$ in the bulk sediments 
was ranged between $26.51 \mu \mathrm{g} / \mathrm{g}$ and $143.57 \mu \mathrm{g} / \mathrm{g}$ with an average of $90.49 \mu \mathrm{g} / \mathrm{g}$, however in the FSG, the leachable Pb was increased from $20.37 \mu \mathrm{g} / \mathrm{g}$ to $106.66 \mu \mathrm{g} / \mathrm{g}$ with an average of $67.24 \mu \mathrm{g} / \mathrm{g}$. Cd leachable in the bulk sediments was insignificant, while in the FSG, Cd leachable was ranged from $0.74 \mu \mathrm{g} / \mathrm{g}$ to $2.60 \mu \mathrm{g} / \mathrm{g}$ averaging of $1.97 \mu \mathrm{g} / \mathrm{g}$. Leachable $\mathrm{Co}$ in the bulk sediments was increased from below the detection limit to $7.70 \mu \mathrm{g} / \mathrm{g}$ averaging of $1.33 \mu \mathrm{g} / \mathrm{g}$ and in the FSG, leachable Co was fluctuated between $3.84 \mu \mathrm{g} / \mathrm{g}$ and $18.66 \mu \mathrm{g} / \mathrm{g}$ with an average of $9.47 \mu \mathrm{g} / \mathrm{g}$ (Table 1).

\section{DISCUSSION}

The variability of carbonates at the studied basins; Port Tawfiq \& Tersana, $44.24 \%$ and $44.93 \%$ indicating to high contributions of the biological activities around and inside these basins including the calcareous debris of corals, other marine shells, shell fragments as well as the anthropogenic activities (precipitation of dust from the quarrying activities of carbonate rocks and loading and unloading operations). Tersana Basin showed high average percentage of total organic matter (TOM\%) (21.70\%) attributed to anthropogenic activities (contamination by the hydrocarbons from the boats and domestic waste and sewage).

The recorded averages at Port Tawfiq $(15.85 \%)$ are mainly attributed to the domestic sewage, the hydrocarbons from the boats, petroleum spilled from the tanks and the boats.

In general, the leachable $\mathrm{Fe}$ in the studied basins showed significantly high occurrences in the FSG group than in the bulk sediment. In the FSG group, Tersana Basin showed the high average content of leachable Fe. The significantly high leachable $\mathrm{Fe}$ at the basins of Port Tawfiq and Tersana may due to the corrosion of constructions and pipes and high organic matter contents that formed high reducing conditions. At the studied harbours; the leachable Fe accompanied with the high FSG distribution (Figs. 2A \& 3A). The average of heavy metals in the bulk sediments and FSG at the studied harbours in comparison with the other studies in Egypt and worldwide were tabulated in (Table 2).

At Port Tawfiq and Tersana basins the high averages of leachable Mn indicating to the effect of the anthropogenic inputs within these basins (boats mooring and repairing, corrosion of constructions and pipes) as well as the reducing conditions inside these basins due to the high percentages of fine sediments and organic matter. Mn patterns at Port Tawfiq and Tersana basins were increased beside the wharf due to the navigation activities, (Figs. 2B \& 3B).

The leachable Zn showed significantly higher contents in the FSG group than in the bulk sediments at Port Tawfiq and Tersana harbours. At Port Tawfiq and Tersana basins, the leachable $\mathrm{Zn}$ increased below the navigation wharfs indicating to the essential source from the maritime activities (Figs. 2C \& 3C).

The leachable $\mathrm{Cu}$ at the studied basins showed significantly higher occurrences in the FSG group than in the bulk sediments. Tersana Basin showed the higher average content of leachable $\mathrm{Cu}$ in FSG than in Port Tawfiq Basin. The distribution patterns of the leachable $\mathrm{Cu}$ showed an increasing beside the wharfs of the navigation basins at Port Tawfiq and Tersana, attributed to the variable maritime activities (Figs. $2 \mathrm{D} \& 3 \mathrm{D})$.

The leachable Ni showed higher contents in the FSG group than in the bulk sediment at the studied basins. The distribution patterns of the leachable Ni at Port Tawfiq and Tersana basins showed the highest contents toward the wharfs indicating to the maritime activities (Figs. 2E \& 3E). 
Table 2: The average values of heavy metals in the bulk and FSG sediments the studied harbours in comparison with the other studies in worldwide.

\begin{tabular}{|c|c|c|c|c|c|c|c|c|c|c|}
\hline \multirow{2}{*}{ Location } & \multicolumn{8}{|c|}{ Heavy metals concentration $(\mu \mathrm{g} / \mathrm{g})$} & \multirow[b]{2}{*}{ Sediment type } & \multirow[b]{2}{*}{ References } \\
\hline & $\mathbf{F e}$ & Mn & $\mathbf{Z n}$ & $\mathbf{C u}$ & $\mathbf{P b}$ & $\mathbf{N i}$ & Co & Cd & & \\
\hline \multirow{2}{*}{$\begin{array}{l}\text { Port Tawfiq } \\
\text { Harbour }\end{array}$} & 2639711 & 21905 & 236.34 & 9801 & 5013 & 26,62 & 858 & 005 & Bulk sediments & \multirow{4}{*}{$\begin{array}{l}\text { Present } \\
\text { study }\end{array}$} \\
\hline & 53382.81 & 625.68 & 594.40 & 303.50 & 211.47 & 55.19 & 11.49 & 0.05 & FSG & \\
\hline \multirow{2}{*}{ Tersana Harbour } & 27761.07 & 224.22 & 265.25 & 209.30 & 62.08 & 30.47 & 6.50 & 0.16 & Bulk sediments & \\
\hline & 60048.82 & 662.55 & 968.58 & 1020.33 & $\mathbf{5 0 7 . 7 5}$ & 67.24 & 9.47 & 1.97 & FSG & \\
\hline \multicolumn{11}{|c|}{ Worldwide harbors } \\
\hline \multirow{2}{*}{$\begin{array}{c}\text { Bremen Seehausen, northern } \\
\text { German }\end{array}$} & - & - & 53 & \multirow{2}{*}{$\begin{array}{rr}9.3 \\
65\end{array}$} & 12 & $<0.05$ & 4.2 & 0.9 & Sandy fraction & \multirow{2}{*}{$\begin{array}{l}\text { Lager et al., } \\
(2005)\end{array}$} \\
\hline & - & - & 490 & & 75 & 41 & 20 & 4.1 & Fine fraction & \\
\hline $\begin{array}{c}\text { Vagen, } \\
\text { Bergen harbour, Norway }\end{array}$ & - & - & 2,900 & 1,090 & 1,920 & - & - & - & Pan fraction & $\begin{array}{l}\text { Paetzel et } \\
\text { al., (2003) }\end{array}$ \\
\hline $\begin{array}{c}\text { Dutch marine harbor } \\
\text { sediments }\end{array}$ & - & - & 510 & 95 & 130 & 43 & - & 4.5 & Bulk sediment & $\begin{array}{l}\text { Stronkhorst } \\
\text { et al., (2003) }\end{array}$ \\
\hline \multirow{2}{*}{ Sydney Estuary, Australia } & - & - & 11300 & 1060 & 1932 & 118 & - & 52 & Bulk sediment & \multirow{2}{*}{$\begin{array}{l}\text { Birch et } \\
\text { al., (2009) }\end{array}$} \\
\hline & - & - & 8446.5 & 1229.5 & 3842 & 119.5 & - & 24 & $(<62.5 \mathrm{~lm})$ & \\
\hline $\begin{array}{c}\text { Guanabara } \\
\text { Bay: Rio de Janeiro, Brazil }\end{array}$ & 4622.8 & - & 377577 & 9421 & 9671 & 20683 & 1758.25 & - & Bulk sediment & $\begin{array}{l}\text { Neto et al., } \\
\text { (2006) }\end{array}$ \\
\hline Haengam Bay, South Korea & 34.1 & - & 159 & & 66.7 & - & - & - & Bulk sediment & $\begin{array}{l}\text { Yoo et al., } \\
(2015)\end{array}$ \\
\hline Gowatr bay-Iran & 2.87 & - & 58.72 & 24.18 & 1666 & 80.16 & 14.99 & - & $<0.063 \mathrm{~mm}$ & $\begin{array}{c}\text { Moore } e t \\
\text { al., (2015) }\end{array}$ \\
\hline $\begin{array}{l}\text { Sardinia, Western } \\
\text { Mediterranean }\end{array}$ & 68.33 & 76.094 & 95.682 & 29.626 & 32.195 & 6.721 & - & 0.681 & Bulk sediment & $\begin{array}{l}\text { Schintu } \text { et } \\
\text { al., } \quad(2015) \\
\text { Schintu, }\end{array}$ \\
\hline English Channel & - & - & 1.12 & 68.4 & - & 31.1 & 113.6 & 3.3 & & \\
\hline Tema Harbour, Ghana & - & 210 & 260 & 100 & 88 & 75 & - & 8.1 & & \\
\hline Quseir Harbour & 12003.17 & 736.77 & 79.62 & 35.83 & 48.24 & 50.99 & 10.74 & 2.10 & & \\
\hline Abu- Tartour Harbour & 15333.33 & 3.33 & 91.67 & 46.6 & 63.33 & 61.67 & 16.17 & 2.50 & Bulk cediment & El-Taher $e t$ \\
\hline Touristic Harbour & 15433.33 & 322.33 & 47.67 & 21.33 & 39.00 & 32.00 & 20.00 & 2.97 & Bulk sedıment & al., (2018) \\
\hline Hurghada Harbour & 7500.00 & 383.3 & 458.33 & $\mathbf{1 0 8 . 3 3}$ & 75.00 & 65.00 & 11.67 & 3.83 & & \\
\hline Batticaloa lagoon, Sri Lanka & 65400 & - & 86.9 & 33.5 & 20.6 & 18.3 & - & - & Bulk sediment & $\begin{array}{l}\text { Adikaram } e t \\
\text { al., (2017) }\end{array}$ \\
\hline Adabiya Harbour & 27153.91 & 182.43 & 180.47 & 67.02 & 19.01 & 62.81 & 6.91 & 0.02 & Bulk sediment & \\
\hline El Zaitiya Harbour & 50924.94 & 532.15 & 377.61 & 195.38 & 54.61 & 145.95 & 7.72 & 0.78 & FSG & Elgendy et \\
\hline & 17777.75 & 155.56 & 134.62 & 35.15 & 15.78 & 20.27 & 12.37 & 0.14 & Bulk sediment & al., (2018) \\
\hline Adabiya Harbour & 43965.42 & 476.88 & 456.94 & 109.42 & 47.35 & 67.12 & 5.65 & 1.01 & FSG & \\
\hline
\end{tabular}


The leachable $\mathrm{Pb}$ showed significantly higher occurrences in the FSG group than in the bulk sediment at the studied basins. The distribution pattern at Port Tawfiq Basin showed increasing toward the wharf, meanwhile Tersana basin showed hot spot in the inner part of the Basin (Figs. 2F \& 3F).
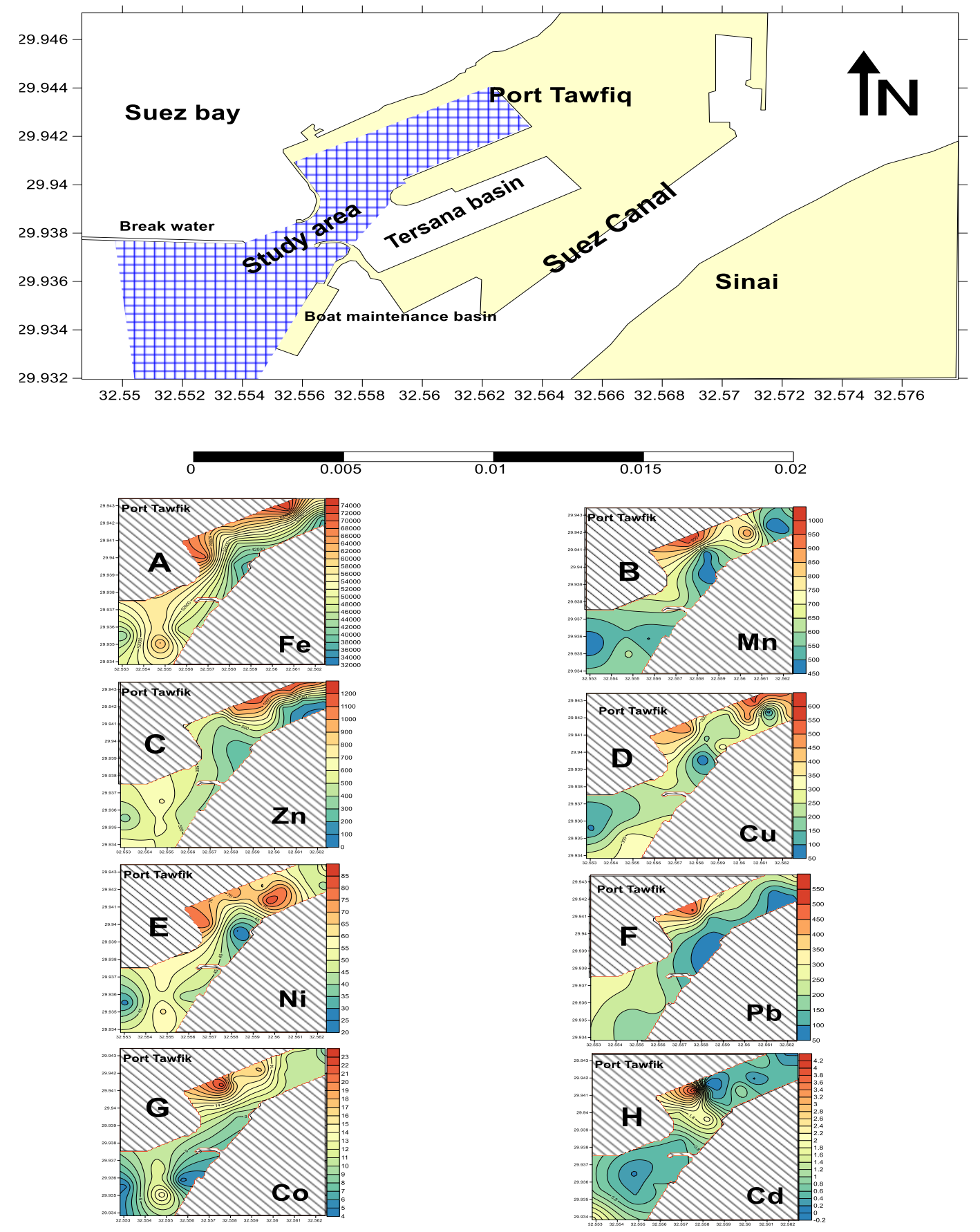

Fig. 2: The distribution pattern of heavy metal contents (FSG) in Port Tawfiq Harbour.

The leachable Co showed significantly higher occurrences in the FSG group than in the bulk sediment at the studied basins. The leachable Co at Port Tawfiq was concentrated in the middle part of the Basin beside the western wharf due to the anthropogenic activities and water movements (waves) within the basin (Fig. 2G). 
The leachable Co at Tersana basin increased patterns inside the basins beside the wharfs due to the maritime activities (Fig. 3G).
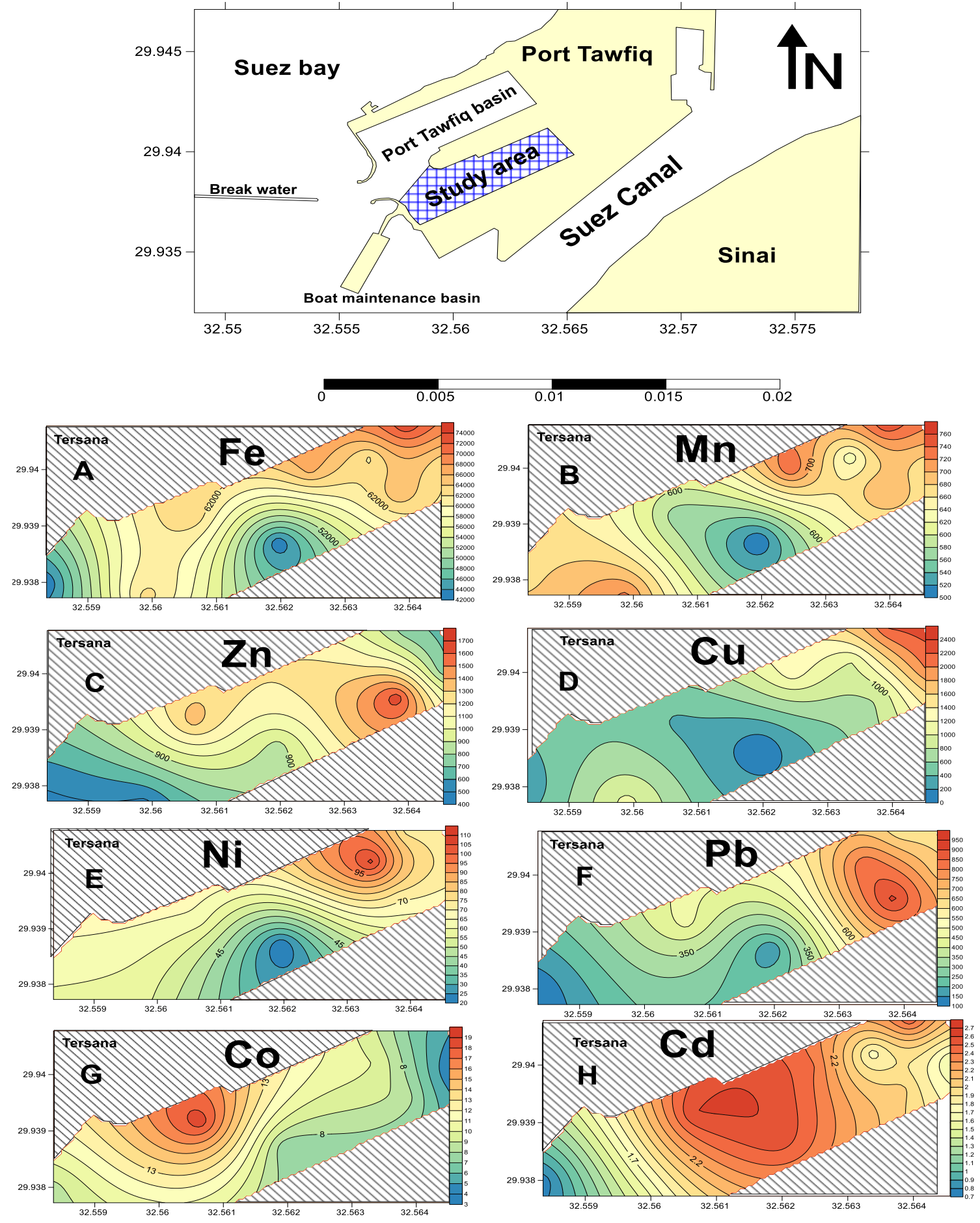

Fig. 3: The distribution pattern of heavy metal contents (FSG) in Tersana Harbour

The leachable Cd showed significantly higher occurrences in the FSG group than in the bulk sediment at the studied basins. Port Tawfiq Basin recorded significant low leachable $\mathrm{Cd}$ values. The FSG showed the highest average of leachable Cd at Tersana Basin relative to at Port Tawfiq Basin (Table 1). 


\section{Correlation coefficients and the uncertainty}

At Port Tawfiq Harbor, Fe showed fair positive correlation with Mn (Fig. 4), strong positive with Zn (Fig. 4) and Ni (Fig. 4) indicating to that Mn, Zn and Ni tend to accumulate with $\mathrm{Fe}$ as oxides. The very strong positive correlation of $\mathrm{Fe}$ with FSG\% ( $\mathrm{r}=0.78)$ indicating to most of $\mathrm{Fe}$ were accumulated in the particulate sediments from anthropogenic sources, meanwhile the positive fair correlation between $\mathrm{Fe}$ and TOM\% $(\mathrm{r}=0.51)$ indicating to the partial accumulation of $\mathrm{Fe}$ as sulfide under the highly reducing conditions. Mn showed the same Fe behavior whereas, the very strong positive correlations of Mn with $\mathrm{Ni}$ (Fig. 4), fair positive with $\mathrm{Pb}(\mathrm{r}=0.59)$ and strong positive with $\mathrm{Co}(\mathrm{r}=0.61)$ indicating to oxidation phases for these metals. The fair negative correlation between $\mathrm{Ni}$ and $\mathrm{CO}_{3} \%$ (Fig. 4) assured the $\mathrm{Ni}$ tendency to accumulate in different forms rather than carbonates. Finally the logic strong positive correlation was found between FSG\% and TOM\% (r $=0.60)$.
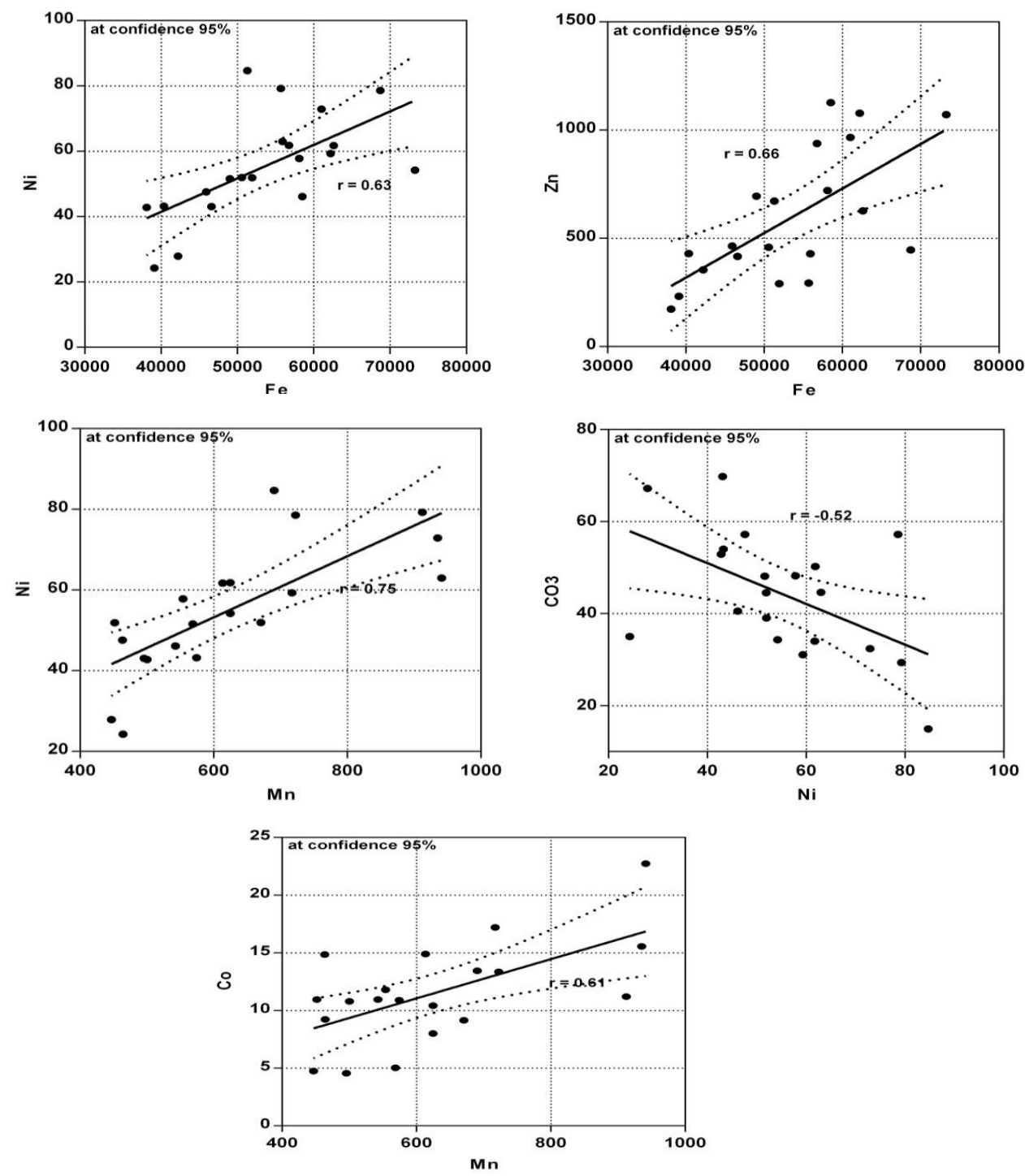

Fig. 4: The Uncertainty relationships of $\mathrm{Fe}$ and $\mathrm{Mn}$ with $\mathrm{Ni}, \mathrm{Zn}, \mathrm{Co}$ and $\mathrm{CO}_{3}$ (at $95 \%$ confidence) at Port Tawfiq Harbour.

As shown in (Fig. 5), at Tersana Harbor, Fe showed strong positive correlation with $\mathrm{Mn}($ Fig. 5), very strong positive with $\mathrm{Cu}(\mathrm{r}=0.74)$, fair positive with $\mathrm{Ni}(\mathrm{r}=$ 
0.59) and strong positive with $\mathrm{Pb}$ (Fig. 5) indicating to that the $\mathrm{Mn}$ and $\mathrm{Pb}$ have the tendency to accumulate with $\mathrm{Fe}$ as oxides indicating to most of $\mathrm{Fe}$ were from anthropogenic sources mainly the maritime activities. The excellent positive correlation between $\mathrm{Fe}$ and TOM\% $(\mathrm{r}=0.88)$ indicating to the partial accumulation of Fe as sulfide under the highly reducing conditions supported by strong positive correlation between $\mathrm{Fe}$ and FSG\% $(\mathrm{r}=0.65)$. Mn showed the same Fe behavior whereas, the strong positive correlations of $\mathrm{Mn}$ with $\mathrm{Cu}(\mathrm{r}=0.69)$ indicating to association in oxidation phase, the fair positive correlations Mn with TOM\% ( $\mathrm{r}=$ 0.55 ) indicating to Mn accumulate as sulfide.
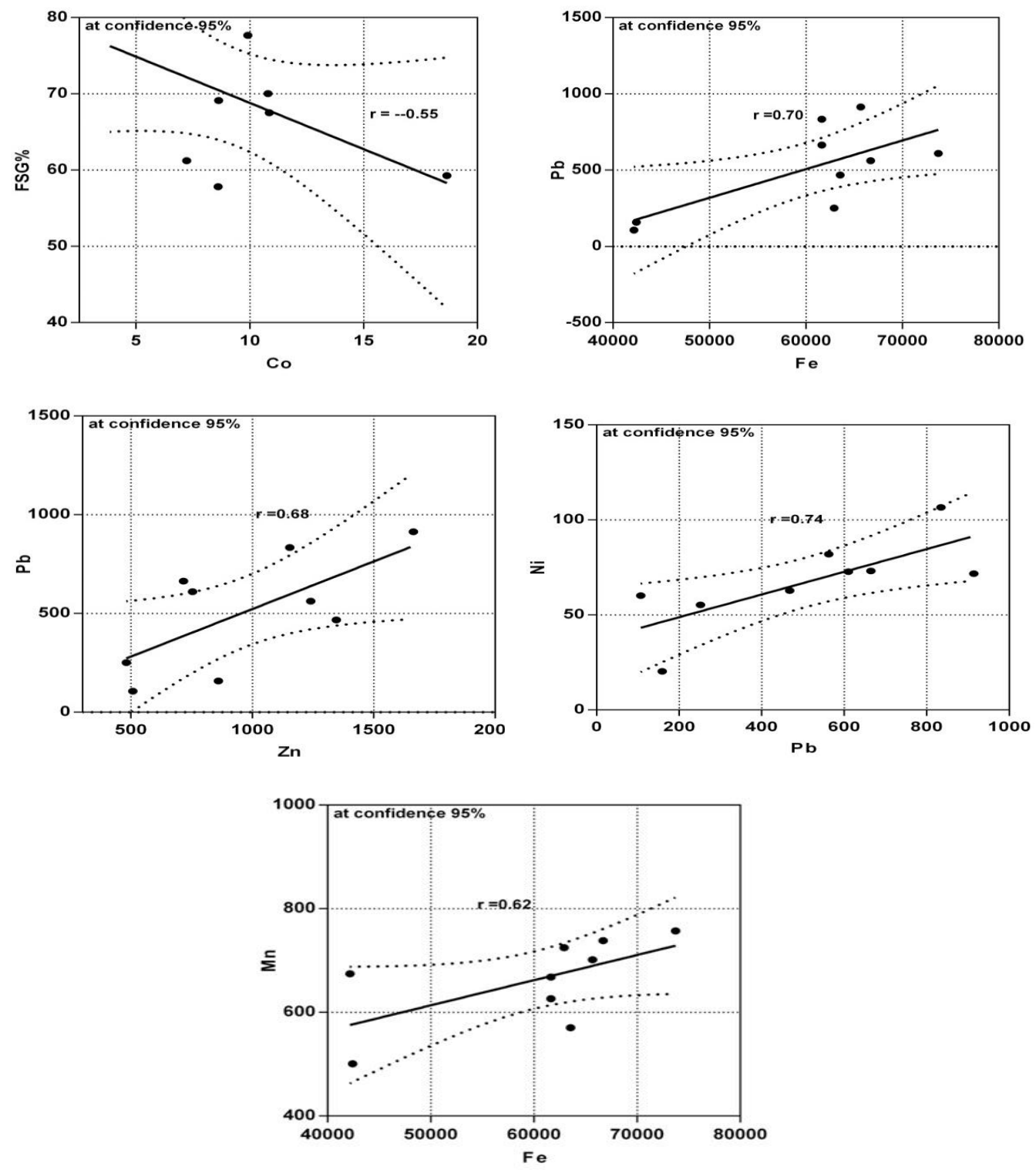

Fig. 5: The Uncertainty relationships of $\mathrm{Fe}, \mathrm{Cu}, \mathrm{Pb}$ and $\mathrm{Co}$ with $\mathrm{Ni}, \mathrm{Mn}$ and FSG (at 95\% confidence) at Tersana Harbour.

The strong positive correlation of $\mathrm{Zn}$ with $\mathrm{Pb}$ (Fig. 5) and fair positive with $\mathrm{Cd}$ $(\mathrm{r}=0.53)$ indicating to these metals accumulated from anthropogenic sources, however the fair positive correlation of $\mathrm{Zn}$ with TOM\% $(\mathrm{r}=0.53)$ indicating to $\mathrm{Zn}$ accumulated as sulfides. The fair positive correlation of $\mathrm{Cu}$ with $\mathrm{Pb}(\mathrm{r}=0.51)$ indicating to the navigation sources, meanwhile the excellent positive correlation of 
$\mathrm{Cu}$ with $\mathrm{FSG} \%(\mathrm{r}=0.91)$ indicating to the maritime sources and the strong positive correlation of $\mathrm{Cu}$ with TOM\% $(\mathrm{r}=0.66)$ indicating to $\mathrm{Cu}$ accumulated as sulfides. The very strong positive correlation of $\mathrm{Ni}$ with $\mathrm{Pb}$ (Fig. 5) indicating to the anthropogenic sources, however the fair positive correlation of Ni with FSG\% ( $r=$ 0.60 ) indicating to the maritime sources and the excellent positive correlation of $\mathrm{Ni}$ with TOM\% $(\mathrm{r}=81)$ indicating $\mathrm{Ni}$ accumulated as sulfides. The strong positive correlation of $\mathrm{Pb}$ with FSG\% $(\mathrm{r}=0.68)$ indicating to navigation sources, however the excellent positive correlation of $\mathrm{Pb}$ with TOM\% $(\mathrm{r}=0.85)$ indicating to $\mathrm{Pb}$ accumulated as sulfides in the reducing environment. The fair negative correlation of Co with FSG\% (Fig. 5) indicating to Co accumulated with another phase. All metals have miscorrelation or negative correlation with $\mathrm{CO}_{3} \%$ assured the heavy metals tendency to accumulate in different forms rather than carbonates and transported by maritime activities. Finally the logic strong positive correlation was found between FSG $\%$ and $\mathrm{TOM} \%(\mathrm{r}=0.64)$.

\section{CONCLUSION}

Port Tawfiq and Tersana Harbours were intensively used in maritime activities; transport of goods and passengers. The heavy metal contaminations in the bottom sediments are derived from different navigation activities (repairing, maintaining and shipyard). These conditions are causing acrimonious ecological risk on the marine ecosystem components such as; sediment nature inside these harbours. The concentration of heavy metals in fine sediment group FSG $(\varnothing 3, \varnothing 4$ and $<\varnothing 4)$ were higher than in the bulk sediments. The FSG are considerably effective in accumulation of the contaminants and transfer to the marine ecosystem. Tersana Harbour recorded higher leachable averages of $\mathrm{Fe}, \mathrm{Mn}, \mathrm{Zn}, \mathrm{Cu}, \mathrm{Ni}, \mathrm{Pb}$ and $\mathrm{Cd}$ than Port Tawfiq Harbour mainly due to the different of maritime activities (maintaining, repairing and shipyard) and the calm conditions. These conditions provide suitable conditions for the metals accumulation under the highly reducing conditions. The distribution patterns of different metals in both basins showed the highest occurrences below the western and northern wharfs of these harbours indicating to that these metals were accumulated mainly from the maritime activities and at the centers due to the eddy currents from the ships motion. Fe showed positive correlation with $\mathrm{Mn}$, $\mathrm{Cu}, \mathrm{Zn}$ and $\mathrm{Ni}$ indicating to that these metals tend to accumulate with $\mathrm{Fe}$ as oxides and indicating to most of Fe were from anthropogenic sources mainly the maritime activities. At Tersana Basin the positive correlation of TOM\% with $\mathrm{Fe}, \mathrm{Mn}, \mathrm{Zn}, \mathrm{Cu}$, $\mathrm{Ni}$ and $\mathrm{Pb}$ indicating to these metals accumulated as sulfides in the reducing environment. All metals have miscorrelation or negative correlation at both harbours with $\mathrm{CO}_{3} \%$ assured the heavy metals tendency to accumulate in different forms rather than carbonates and transported by maritime activities. Fe and Mn have nearly showed the same distribution patterns. Most of the heavy metals increased beside or below the wharfs due to the effect of the maritime activities.

\section{REFERENCES}

Abrahim, G. M. S.; Parker, R. and Nichol, S. (2007). Distribution and assessment of sediment toxicity in Tamaki Estuary, Auckland, New Zealand. Environmental Geology, 52(7):1315-1323.

Adikaram, M.; Pitawala, A.; Ishiga, H. and Jayawardana, D. (2017). Spatial distribution, enrichment, and source of environmentally important elements in 
Batticaloa lagoon, Sri Lanka. Environmental Science and Pollution Research, 24(2): 2089-2099.

Basaham, A. S. and El Sayed, M. A. (1998). Distribution and phase association of some major and trace elements in the Arabian Gulf sediments. Estuarine, Coastal and Shelf Science, 46(2):185-194.

Behairy, A. K.; Sheppard, C. R. and El-Sayed, M. K. (1992). A review of the geology of coral reefs in the Red Sea. UNEP Regional Seas Reports and Studies, 152: 41.

Birch, G. F. and Hutson, P. (2009). Use of sediment risk and ecological/conservation value for strategic management of estuarine environments: Sydney estuary, Australia. Environmental management, 44(4): 836-850.

Botwe, B. O.; Alfonso, L.; Nyarko, E. and Lens, P. N. (2017). Metal distribution and fractionation in surface sediments of coastal Tema Harbour (Ghana) and its ecological implications. Environmental Earth Sciences, 76(15): 514.

Brenner, M. and Binford, M. W. (1988). Relationships between concentrations of sedimentary variables and trophic state in Florida lakes. Canadian Journal of Fisheries and Aquatic Sciences, 45(2): 294-300.

Dar, M. A. and El-Saharty, A. A. (2006). Recycling and retention of some trace metals in the mangrove sediments, Red Sea, Egypt. Egyptian Journal of Aquatic esearch, 32(2): 34-47.

Dar, M. A.; El-Metwally, M. E. and El-Moselhy, K. M. (2016a). Distribution patterns of mobile heavy metals in the inshore sediments of the Red Sea. Arabian Journal of Geosciences, 9(3):1-14.

Dean Jr, W. E. (1974). Determination of carbonate and organic matter in calcareous sediments and sedimentary rocks by loss on ignition: comparison with other methods. Journal of Sedimentary Research, 44(1).

Elgendy, A.; Soliman, F.; Dar, M.; Hassan, A.; Mohamedein, L. and Hassaan, M. (2018). 'Evaluation of some leachable heavy metals in the Seafloor sediments of the two navigation Harbours El Zaitiya and Adabiya, Gulf of Suez, Egypt', Egyptian Journal of Aquatic Biology and Fisheries, 22(4): 77-92.

El-Rayis, O.A.; Hassaan, M. A. and Hemada, E. I. (2014). Suitability of Lake Mariut Drainage System (Qalaa and Umum Drains Waters) for Water Reuse, Blue Biotechnology Journal, 3(2): 265-277.

El-Taher, A.; Zakaly, H. M. and Elsaman, R. (2018). Environmental implications and spatial distribution of natural radionuclides and heavy metals in sediments from four harbours in the Egyptian Red Sea coast. Applied Radiation and Isotopes, 131: $13-22$.

Flannery, M. S., Snodgrass, R. D. and Whitmore, T. J. (1982). Deep water sediments and trophic conditions in Florida lakes. Hydrobiologia 92: 597-602.

Folk, R. L. (1974). Petrology of Sedimentary Rocks: The University of Texas, Geology 370 K, 383 L, 383 M: Hemphill.

Fouda, M. M. and Gerges, M. A. (1994). Implications of climate change in the Red Sea and Gulf of Aden Region: An Overview. UNEP Regional Seas Reports and Studies No. 156, 99p.

Garcia, G.; Manteca, J. I. and Peñas, J. M. (2007). Leaching and transport of Zn through soil profiles in a seasonal river of a mining area in SE Spain. Global NEST J 9(3): 214-223.

GARSP, (2017). General Authority of Red Sea Ports (Wib site).

Hamdoun, H.; Van-Veen, E.; Basset, B.; Lemoine, M.; Coggan, J.; Leleyter, L. and Baraud, F. (2015). Characterization of harbor sediments from the English 
Channel: assessment of heavy metal enrichment, biological effect and mobility. Marine pollution bulletin, 90(1-2): 273-280.

Hassaan, M. A. and Ali, H. R. (2017). Fresh Water Pollution and Heavy Metals Removal. 1st Edition, Publisher: Lambert Academic publishing, e-book [ISBN: 978-3-659-57770-3]. pp. 220

Lager, T.; Hamer, K., and Schulz, H. D. (2005). Mobility of heavy metals in harbour sediments: an environmental aspect for the reuse of contaminated dredged sediments. Environmental Geology, 48(1): 92-100.

Martínez-Sánchez. M. J; Navarro, M. C. ; Pérez-Sirvent, C.; Marimón. J.; Vidal, J.; García-Lorenzo, M. L. and Bech, J. (2008). Assessment of the mobility of metals in a mining-impacted coastal area (Spain, western Mediterranean). J Geochem Explor 96: 171-182.

Mohamed A. Hassaan.; Osman A. El-Rayis and Engy I. Hemada (2017). Estimation of the Redox Potential of Lake Mariut Drainage System (Qalaa and Umum Drains), Hydrology, 5(6): 82-85.

Mohamed A. Hassaan; Ahmed El Nemr and Fedekar F. Madkour (2016). Environmental Assessment of Heavy Metal Pollution and Human Health Risk, American Journal of Water Science and Engineering., 2 (3): 14-19.

Mohamed.A. Hassaan and O. A. El-Rayis (2018). Calculations and Solutions for Heavy Metals Pollution Load from Umum and Qalaa Drains to Lake Mariut, Egypt. INDIAN J. MAR. SCI., 47 (07): 1460-1467.

Mohamed A. Hassaan, Ahmed El Nemr and Fedekar F. Madkour, 2017b. Advanced oxidation processes of Mordant Violet 40 dye in freshwater and seawater. Egypt. J. Aquat. Res. 43, 1-9.

Moore, F.; Nematollahi, M. J. and Keshavarzi, B. (2015). Heavy metals fractionation in surface sediments of Gowatr bay-Iran. Environmental monitoring and assessment, 187(1), 4117.

Neto, J. A. B.; Gingele, F. X.; Leipe, T., and Brehme, I. (2006). Spatial distribution of heavy metals in surficial sediments from Guanabara Bay: Rio de Janeiro, Brazil. Environmental Geology, 49(7): 1051-1063.

Nobi, E.; Dilipan, E.; Thangaradjou, T.; Sivakumar, K. and Kannan, L. (2010). Geochemical and geo-statistical assessment of heavy metal concentration in the sediments of different coastal ecosystems of Andaman Islands, India. Estuarine, Coastal and Shelf Science, 87(2): 253-264.

Paetzel, M.; Nes, G.; Leifsen, L., and Schrader, H. (2003). Sediment pollution in the Vågen, Bergen harbour, Norway. Environmental Geology, 43(4): 476-483.

SCA, (2016). Suez Canal Authority. (https://www.suezcanal.gov.eg/Arabic/Pages/default.aspx). Last access 23/9/2018.

Schintu, M.; Buosi, C.; Galgani, F.; Marrucci, A.; Marras, B.; Ibba, A. and Cherchi, A. (2015). Interpretation of coastal sediment quality based on trace metal and PAH analysis, benthic foraminifera, and toxicity tests (Sardinia, Western Mediterranean). Marine pollution bulletin, 94(1-2): 72-83.

Stronkhorst, J. and Van Hattum, B. (2003). Contaminants of concern in Dutch marine harbor sediments. Archives of environmental contamination and toxicology, 45(3): 306-316.

UNEP, (1997). Assessment of land-based sources and activities affecting the marine environment in the Red Sea and Gulf of Aden. Untied Nation environment Program (UNEP), Regional seas reports and studies, 166:62p. 
Yoo, J. C.; Yang, J. S.; Jeon, E. K. and Baek, K. (2015). Enhanced-electrokinetic extraction of heavy metals from dredged harbor sediment. Environmental Science and Pollution Research, 22(13): 9912-9921.

\section{ARABIC SUMMARY}

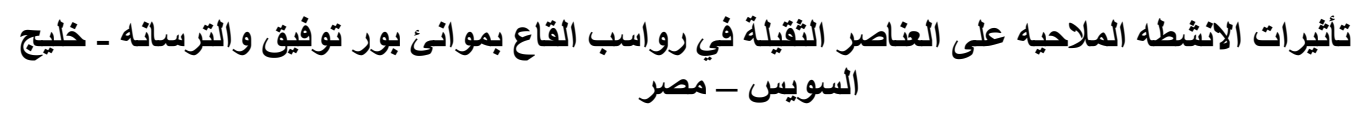

أحمد ربيع الجندي 1 ، محم على حسان 1*، فاروق أحمد سليمان² ، محمود عبد الراضي دار 1

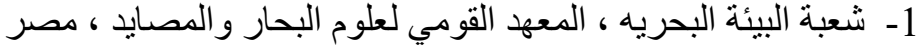

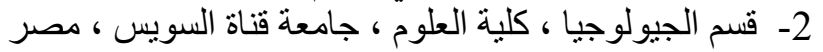

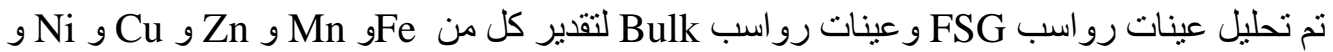

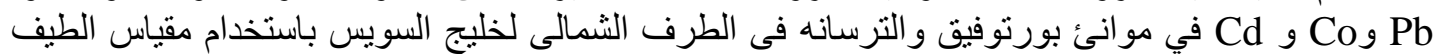

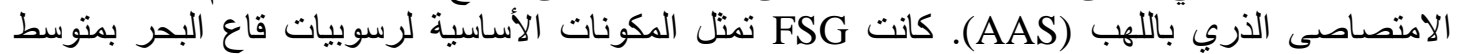

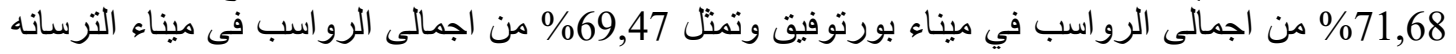

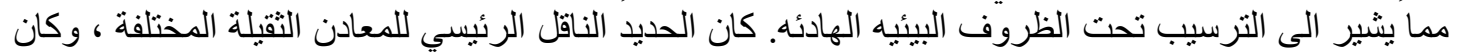

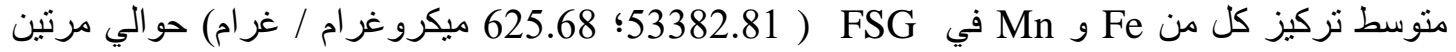

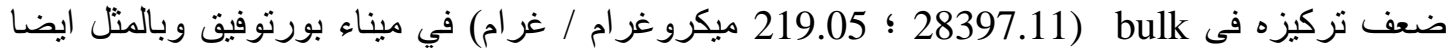

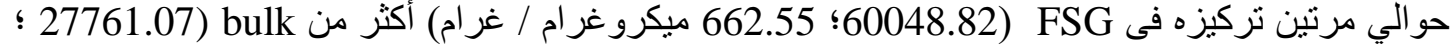
224.22 ميكرو غر ام / غر ام) في ميناء الترسانه. 